\title{
Aleksandra Ferens
}

Uniwersytet Ekonomiczny w Katowicach e-mail: aleksandra.ferens@ue.katowice.pl

ORCID 0000-0003-2346-9904

\section{INFORMACJE NIEFINANSOWE W SPRAWOZDAWCZOŚCI SPÓEEK BRANŻY ENERGETYCZNEJ}

\section{NON-FINANCIAL INFORMATION IN REPORTING BY ENERGY COMPANIES}

DOI: $10.15611 /$ pn.2019.11.01

JEL Classification: M14

Streszczenie: Opracowanie przedstawia wnioski (wnioskowanie dedukcyjne i indukcyjne) z oceny formy i zakresu informacji niefinansowych prezentowanych przez przedsiębiorstwa branży energetycznej. Przeprowadzona analiza stanowi także próbę oceny poszczególnych obszarów raportowanych danych niefinansowych w kontekście podstawowych cech jakościowych sprawozdania finansowego. Obiektem badań są sprawozdania czterech największych spółek energetycznych w Polsce: PGE, Enei, Energi i Tauronu. Artykuł jest oparty na studiach polskich i zagranicznych artykułów, aktów prawnych oraz weryfikacji zawartości wybranych raportów zarządczych sporządzonych przez przedsiębiorstwa branży energetycznej. Prezentowane przez przedsiębiorstwa branży energetycznej informacje niefinansowe wpływają na wybrane cechy jakościowe sprawozdania z działalności, takie jak: użyteczność, przydatność, przejrzystość, czytelność, spójność, terminowość, porównywalność, wiarygodność.

Słowa kluczowe: informacje niefinansowe, cechy jakościowe sprawozdania, zintegrowane raportowanie.

Summary: The paper presents the conclusions (deductive and inductive inference) from the assessment of the form and scope of non-financial information presented by energy industry companies. The analysis is also an attempt to assess individual areas of the reported non-financial data in the context of the basic qualitative features of the financial statements. The object of research is the reports of four largest energy companies in Poland: PGE, Enea, Energi, and Tauron. The article is based on the study of Polish and foreign articles, legal acts and verification of the content of selected management reports prepared by energy industry companies. Non-financial information presented by energy companies affects selected quality features of the activity report, such as: usability, usefulness, transparency, readability, consistency, timeliness, comparability, reliability.

Keywords: non-financial information, qualitative features of the report, integrated reporting. 


\section{Wstęp}

Rachunkowość jako nauka podlega ciągłym przeobrażeniom i ewolucji, co spowodowane jest zmianami gospodarczymi, społecznymi i środowiskowymi oraz rosnącą świadomością społecznej odpowiedzialności przedsiębiorstw. Wywiązywanie się z odpowiedzialności względem środowiska i społeczności realizowane jest m.in. poprzez raportowanie informacji niefinansowych.

W literaturze z rachunkowości i finansów nie ma jednej powszechnie przyjętej definicji informacji niefinansowych. Polscy autorzy, którzy podjęli się próby zdefiniowania tego pojęcia, to m.in.: Samelak [2013, s. 7-8], Sobczyk [2017, s. 396], Zyznarska-Dworczak [2016, s. 219], Walińska, Bek-Gaik, Gad [2018, s. 170-173]. Wśród zagranicznych autorów na uwagę zasługują Gernon, Meek [2001, s. 71-72], Gazdar [2007, s. 2], Stolowy i Paugam [2018].

Szeroką propozycję definicji informacji niefinansowych przedstawia Krasodomska [2014, s. 28], według której obejmują one wszelkie informacje (opisowe i liczbowe, przy czym niekoniecznie wyrażone w mierniku pieniężnym) publikowane (obowiązkowo lub dobrowolnie) w ramach rocznego raportu przedsiębiorstwa, poza sprawozdaniem finansowym oraz opinią i raportem biegłego rewidenta. Dużą popularnością cieszy się natomiast wąska definicja informacji niefinansowych prezentowana w dyrektywie 2014/95/UE, w której informacje niefinansowe ograniczone są do zagadnień „łączonych” z koncepcją społecznej odpowiedzialności biznesu (CSR - Corporate Social Responsibility) [Bek-Gaik, Krasodomska 2018]. Biorąc pod uwagę proces decyzyjny realizowany w podmiotach gospodarczych, autorka artykułu uważa, że informacjami niefinansowymi należałoby określić wszelkie rodzaje informacji (zarówno te o charakterze mierzalnym, jak i niemierzalnym), które identyfikują problemy powstające na styku przedsiębiorstwo - środowisko przyrodnicze - społeczeństwo i przyczyniają się do realizacji zasad zrównoważonego i trwałego rozwoju. Wyraźny wzrost znaczenia sprawozdawczości niefinansowej, wymuszony m.in. zwiększaniem potrzeb informacyjnych poszczególnych grup interesariuszy, ma obecnie swój wyraz w zapisach Ustawy o Rachunkowości (art. 49b), która obliguje do prezentowania informacji niefinansowych duże spółki kapitałowe. Praktyka ujawnień informacji niefinansowych została wprowadzona w celu zwiększenia ich porównywalności, wiarygodności, przejrzystości i spójności. Duży wpływ na zakres prezentowanych informacji niefinansowych miała także Rada Standardów Rachunkowości Finansowej (FASB), która wprowadziła konieczność raportowania danych niefinansowych wraz z tradycyjnym sprawozdaniem finansowym [Luft 2009; Maines i in. 2002; Upton 2001].

Celem artykułu jest próba oceny poszczególnych obszarów raportowanych danych niefinansowych w kontekście podstawowych cech jakościowych sprawozdania finansowego na przykładzie przedsiębiorstw branży energetycznej. Dokonano także próby odpowiedzi na pytanie: czy rzeczywiście informacje niefinansowe prezentowane przez przedsiębiorstwa branży energetycznej w sprawozdaniu rocznym 
za 2018 rok umożliwiają porównywalność danych niefinansowych? Czy zwiększyła się dotychczasowa spójność i zrozumiałość prezentowanych informacji z zakresu odpowiedzialności społecznej? Na podstawie analizy sprawozdań rocznych czterech największych spółek energetycznych w Polsce za 2018 rok autorka ustosunkowuje się także do zachowania i przestrzegania innych wybranych cech jakościowych sprawozdania z działalności.

\section{Zakres informacji niefinansowych w sprawozdawczości jednostek gospodarczych sporządzanych według ustawy o rachunkowości}

Nowelizacja ustawy o rachunkowości wprowadziła rozbudowane wymogi raportowania danych niefinansowych w odniesieniu do dużych jednostek. Zmodyfikowane wymogi dotyczą sprawozdań sporządzanych za rok obrotowy rozpoczynający się od 1 stycznia 2017 roku. Podmiotami objętymi regulacją są duże jednostki zainteresowania publicznego, które zostały wymienione w art. 3 ust. 1e pkt 1-6 ustawy, tj.:

a) jednostki organizacyjne działające na podstawie przepisów prawa bankowego, przepisów o obrocie papierami wartościowymi, przepisów o funduszach inwestycyjnych, przepisów o działalności ubezpieczeniowej i reasekuracyjnej, przepisów o organizacji i funkcjonowaniu funduszy emerytalnych, bez względu na wielkość przychodów,

b) jednostki zamierzające ubiegać się albo ubiegające się o zezwolenie na wykonywanie działalności na podstawie przepisów, o których mowa w ww. pkt a,

c) emitenci papierów wartościowych dopuszczonych, zamierzających ubiegać się lub ubiegających się o ich dopuszczenie do obrotu na jednym z rynków regulowanych Europejskiego Obszaru Gospodarczego,

d) emitenci papierów wartościowych dopuszczonych do obrotu w alternatywnym systemie obrotu,

e) krajowe instytucje płatnicze,

f) instytucje pieniądza elektronicznego, które są spółkami kapitałowymi, spółkami komandytowo-akcyjnymi lub takimi spółkami jawnymi lub komandytowymi, których wszystkimi wspólnikami ponoszącymi nieograniczoną odpowiedzialność są spółki kapitałowe lub spółki komandytowo-akcyjne bądź spółki z innych państw o podobnej do tych spółek formie prawnej, i w roku obrotowym, za który sporządzają sprawozdanie finansowe, oraz $\mathrm{w}$ roku poprzedzającym ten rok przekroczyły następujące wartości:

- średnioroczne zatrudnienie w przeliczeniu na pełne etaty - 500 osób oraz

- suma aktywów bilansu - 85 mln zł lub przychody netto ze sprzedaży towarów i produktów - $170 \mathrm{mln}$ zł.

Jednostki zobowiązane do raportowania informacji niefinansowych mają wybór formy tego raportowania. Mogą zamieszczać wymagane informacje w ramach: 
- sprawozdania z działalności (jako oświadczenie na temat informacji niefinansowych),

- odrębnego sprawozdania na temat informacji niefinansowych (należy je umieścić na stronie internetowej w terminie 6 miesięcy od dnia bilansowego).

Zgodnie z ustawą o rachunkowości oświadczenie na temat informacji niefinansowych powinno zawierać co najmniej:

1) zwięzły opis modelu biznesowego jednostki;

2) kluczowe niefinansowe wskaźniki efektywności związane z działalnością jednostki;

3) opis polityk stosowanych przez jednostkę w odniesieniu do zagadnień społecznych, pracowniczych, środowiska naturalnego, poszanowania praw człowieka oraz przeciwdziałania korupcji, a także opis rezultatów stosowania tych polityk;

4) opis procedur należytej staranności - jeżeli jednostka je stosuje w ramach polityk, o których mowa w pkt 3;

5) opis istotnych rodzajów ryzyka związanych z działalnością jednostki mogących wywierać niekorzystny wpływ na zagadnienia, o których mowa w pkt 3 , w tym ryzyka związanego z produktami jednostki lub jej relacjami z otoczeniem zewnętrznym, w tym z kontrahentami, a także opis zarządzania tymi ryzykami.

\section{Ocena wybranych obszarów raportowanych danych niefinansowych w jednostkach branży energetycznej}

Ustawa o rachunkowości zobowiązuje do sporządzenia informacji niefinansowych w formie oświadczenia lub odrębnego sprawozdania na poziomie jednostki i/oraz grupy. Analiza formy raportów rocznych czterech największych spółek branży energetycznej została przedstawiona w tab. 1.

Jak wynika z tab. 1, przedsiębiorstwa PGE oraz Energa skorzystały z możliwości prezentowania odrębnego sprawozdania, jakie dopuszcza ustawa. Tauron oraz Enea opublikowały natomiast oświadczenie na temat informacji niefinansowych w ramach sprawozdania zarządu z działalności. Ponadto spółka Tauron opublikowała zarazem oświadczenie i raport zintegrowany. Jest to dość nietypowa sytuacja, ale ustawa nie zabrania, aby informacje niefinansowe były prezentowane podwójnie. Biorąc pod uwagę aspekty formalne prezentowania informacji finansowych, można stwierdzić, że wszystkie cztery spółki zastosowały się do tzw. dobrych praktyk, ponieważ jednostki sporządzające odrębne sprawozdania, a także te sporządzające informacje niefinansowe $\mathrm{w}$ ramach oświadczenia prawidłowo je zaprezentowały i nazwały ${ }^{1}$.

${ }^{1}$ Częstym błędem w przypadku jednostek sporządzających odrębne sprawozdania jest nazwanie tych sprawozdań „oświadczeniem” lub „integralną częścią sprawozdania z działalności”. Jednostki sporządzające informacje niefinansowe w ramach oświadczenia popełniają natomiast błąd, nazywając to sprawozdanie „sprawozdanie z działalności niefinansowej” [Raportowanie 2019]. 
Tabela 1. Forma prezentowania informacji niefinansowych przez przedsiębiorstwa branży energetycznej

\begin{tabular}{|l|l|l|l|}
\hline $\begin{array}{l}\text { Nazwa jednostki } \\
\text { gospodarczej }\end{array}$ & $\begin{array}{l}\text { Nazwa raportu, gdzie znajduje } \\
\text { się informacja o sporządzeniu } \\
\text { informacji niefinansowych }\end{array}$ & $\begin{array}{c}\text { Wybór formy prezentowania } \\
\text { informacji niefinansowych }\end{array}$ & $\begin{array}{c}\text { Strona } \\
\text { internetowa }\end{array}$ \\
\hline Energia SA & $\begin{array}{l}\text { Jednostkowy Raport Roczny } \\
\text { TAURON } \\
\text { Polska Energia SA za rok } \\
2018\end{array}$ & $\begin{array}{l}\text { Oświadczenie na temat informacji } \\
\text { niefinansowych prezentowane } \\
\text { w ramach sprawozdania } \\
\text { z działalności, a także raport } \\
\text { zintegrowany za 2018 rok }\end{array}$ & Tak \\
\hline $\begin{array}{l}\text { PGE - Polska } \\
\text { Energetyczna }\end{array}$ & $\begin{array}{l}\text { PGE Polska Grupa } \\
\text { Energetyczna SA. } \\
\text { Jednostkowe Sprawozdanie } \\
\text { finansowe za rok 2018 }\end{array}$ & $\begin{array}{l}\text { Sprawozdanie na temat informacji } \\
\text { niefinansowych PGE Polskiej } \\
\text { Grupy Energetycznej SA oraz } \\
\text { Grupy Kapitałowej PGE za 2018 } \\
\text { rok (osobne sprawozdanie) }\end{array}$ & Tak \\
\hline Energa & $\begin{array}{l}\text { Sprawozdanie Zarządu } \\
\text { Energi SA z działalności } \\
\text { Grupy Kapitałowej za rok } \\
\text { zakończony dnia 31 grudnia } \\
\text { 2018 roku }\end{array}$ & Raport CSR & Tak \\
\hline Enea & $\begin{array}{l}\text { Sprawozdanie Zarządu } \\
\text { z działalności Enea SA oraz } \\
\text { grupy kapitałowej Enea } \\
\text { w 2018 roku }\end{array}$ & $\begin{array}{l}\text { Oświadczenie na temat } \\
\text { informacji niefinansowych Grupy } \\
\text { Kapitałowej Enea }\end{array}$ & Tak \\
\hline
\end{tabular}

Źródło: opracowanie własne.

W myśl założeń koncepcyjnych sprawozdawczości finansowej sprawozdania finansowe powinny obejmować zbiór informacji użytecznych dla interesariuszy sprawozdań. Fundamentalnymi cechami jakościowymi użytecznej informacji jest ich przydatność i wierna prezentacja. Chociaż cechy te odnoszą się do informacji finansowych, autorka uważa, że należy je także odnieść do prezentowania informacji niefinansowych. Użytecznymi informacjami (zarówno finansowymi, jak i niefinansowymi) będą zatem wszystkie te, które mogą być przydatne obecnym i potencjalnym inwestorom, kredytodawcom i innym wierzycielom przy podejmowaniu decyzji. MSSF wskazują przydatność jako jedną z fundamentalnych cech jakościowych sprawozdawczości finansowej, kierując rachunkowość na tory rachunkowości zarządczej, co w odniesieniu do założeń sprawozdawczości zintegrowanej, CSR oraz idei prezentowania informacji niefinansowych powoduje, że przydatność może być traktowana jako ich cecha priorytetowa. Informacja użyteczna powinna być ponadto rzetelna, jasna, wiarygodna [Rówińska 2013].

Uzupełnieniem cech podstawowych są cechy dodatkowe: porównywalność (comparability), sprawdzalność (verifiability), terminowość (timeliness), zrozumiałość (understability) [Jaruga i in. 2009, s. 29-30]. 
W celu oceny użyteczności sprawozdawczości zintegrowanej należy odnieść się do przydatności tych informacji dla interesariuszy i określić, czy sporządzone sprawozdania zawierają informacje istotne, kompletne i uwzględniające oczekiwania co do zakresu dostarczonych informacji [Szczepankiewicz 2013]. Sprawozdanie prezentujące informacje niefinansowe powinno zawierać zagadnienia i wskaźniki, które obejmują istotne oddziaływania przedsiębiorstwa na środowisko przyrodnicze i społeczność, a także relacje/interakcje istniejące między nimi. W celu dokonania oceny użyteczności prezentowanych informacji niefinansowych autorka dokonała zestawienia informacji wymaganych do zaprezentowania zgodnie z ustawą o rachunkowości z tymi, które prezentują analizowane jednostki gospodarcze (tab. 2).

Tabela 2. Zakres informacji niefinansowych w sprawozdawczości spółek energetycznych

\begin{tabular}{|c|c|c|c|c|}
\hline Charakterystyka & $\begin{array}{c}\text { Tauron Polska } \\
\text { Energia SA }\end{array}$ & $\begin{array}{c}\text { PGE - } \\
\text { Polska Grupa } \\
\text { Energetyczna }\end{array}$ & Energa & Enea \\
\hline 1 & 2 & 3 & 4 & 5 \\
\hline $\begin{array}{l}\text { Zwięzły opis modelu } \\
\text { biznesowego } \\
\text { jednostki }\end{array}$ & $\begin{array}{l}\text { W modelu } \\
\text { biznesowym } \\
\text { i operacyjnym } \\
\text { grupy opisano } \\
\text { syntetycznie: } \\
\text { 1. Założenia } \\
\text { modelu } \\
\text { biznesowego } \\
\text { i operacyjnego } \\
\text { grupy } \\
\text { 2. Zasady } \\
\text { zarządzania } \\
\text { spółką } \\
\text { 3. Obszary } \\
\text { biznesowe } \\
\text { grupy } \\
\text { kapitałowej } \\
\text { 4. Zmiany } \\
\text { w zasadach } \\
\text { zarządzania }\end{array}$ & $\begin{array}{l}\text { W łącznym } \\
\text { sprawozdaniu } \\
\text { niefinansowym } \\
\text { PGE } \\
\text { przedstawiono } \\
\text { krótki opis } \\
\text { oraz schemat } \\
\text { uwzględniający } \\
\text { najważniejsze } \\
\text { elementy modelu } \\
\text { biznesowego } \\
\text { grupy kapitałowej } \\
\text { PGE i model } \\
\text { biznesowy PGE } \\
\text { SA, segmenty } \\
\text { działalności } \\
\text { oraz schemat } \\
\text { bezpośredniego } \\
\text { zaangażowania }\end{array}$ & $\begin{array}{l}\text { Opis modelu } \\
\text { zawiera } \\
\text { szczegółową } \\
\text { charakterystykę } \\
\text { struktury firmy, } \\
\text { a także sposób } \\
\text { budowy wartości } \\
\text { w podziale na linie } \\
\text { biznesowe }\end{array}$ & $\begin{array}{l}\text { Raport zawiera } \\
\text { bardzo przejrzysty } \\
\text { i zwięzły } \\
\text { opis modelu } \\
\text { biznesowego. } \\
\text { Na początku } \\
\text { wymieniono } \\
5 \text { głównych } \\
\text { przedmiotów } \\
\text { działalności } \\
\text { i przypisano } \\
\text { do nich spółki } \\
\text { z grupy. Następnie } \\
\text { wymieniono } 4 \\
\text { obszary biznesowe } \\
\text { - wytwarzanie, } \\
\text { wydobycie, } \\
\text { dystrybucję } \\
\text { i obrót. W dalszej } \\
\text { kolejności podano } \\
\text { informację o misji } \\
\text { i wizji grupy }\end{array}$ \\
\hline $\begin{array}{l}\text { Kluczowe } \\
\text { niefinansowe } \\
\text { wskaźniki } \\
\text { efektywności } \\
\text { związane } \\
\text { z działalnością } \\
\text { jednostki }\end{array}$ & $\begin{array}{l}\text { Kluczowe } \\
\text { wskaźniki są } \\
\text { przedstawione } \\
\text { opisowo, } \\
\text { np. wskaźnik } \\
\text { częstotliwości } \\
\text { przerw }\end{array}$ & $\begin{array}{l}\text { Raport } \\
\text { uwzględnia: } \\
\text { kluczowe } \\
\text { wskaźniki } \\
\text { w obszarze } \\
\text { informacji } \\
\text { środowiskowych, }\end{array}$ & $\begin{array}{l}\text { W raporcie } \\
\text { uwzględniono } \\
\text { wiele wskaźników } \\
\text { w podziale na pięć } \\
\text { najważniejszych } \\
\text { obszarów } \\
\text { społecznej }\end{array}$ & $\begin{array}{l}\text { Dobrą praktyką } \\
\text { spółki jest } \\
\text { ujawnienie } \\
\text { wartości } \\
\text { kluczowych } \\
\text { niefinansowych } \\
\text { wskaźników }\end{array}$ \\
\hline
\end{tabular}




\begin{tabular}{|c|c|c|c|c|}
\hline 1 & 2 & 3 & 4 & 5 \\
\hline & $\begin{array}{l}\text { w dostawach } \\
\text { energii (SAIDI), } \\
\text { liczba inicjatyw } \\
\text { badawczo- } \\
\text {-rozwojowych } \\
\text { i innowacyjnych, } \\
\text { satysfakcja } \\
\text { klienta (wskaźnik } \\
\text { CSI) }\end{array}$ & $\begin{array}{l}\text { które } \\
\text { zaprezentowano } \\
\text { zgodnie } \\
\text { z wytycznymi } \\
\text { Global Reporting } \\
\text { Initiative (GRI), } \\
\text { wskaźniki ryzyka, } \\
\text { wskaźniki } \\
\text { satysfakcji, } \\
\text { wskaźniki } \\
\text { w obszarze kwestii } \\
\text { pracowniczych }\end{array}$ & $\begin{array}{l}\text { odpowiedzialności } \\
\text { przedsiębiorstwa. } \\
\text { W sprawozdaniu } \\
\text { tym opisano } \\
\text { także wskaźniki } \\
\text { dotyczące } \\
\text { informacji } \\
\text { środowiskowych } \\
\text { zgodnie } \\
\text { z wytycznymi } \\
\text { GRI. Brak jest } \\
\text { wyszczególnienia } \\
\text { wskaźników } \\
\text { kluczowych }\end{array}$ & $\begin{array}{l}\text { efektywności } \\
\text { w porównaniu } \\
\text { za lata } 2016 \text { oraz } \\
2017\end{array}$ \\
\hline $\begin{array}{l}\text { Opis polityk } \\
\text { stosowanych } \\
\text { przez jednostkę } \\
\text { w odniesieniu do } \\
\text { zagadnień: } \\
\text { - społecznych, } \\
\text { - pracowniczych, } \\
\text { - środowiska } \\
\text { naturalnego, } \\
\text { - poszanowania } \\
\text { praw człowieka } \\
\text { - przeciwdziałania } \\
\text { korupcji }\end{array}$ & $\begin{array}{l}\text { Jednostka } \\
\text { dokonała opisu } \\
\text { polityk odnośnie } \\
\text { do wszystkich } \\
5 \text { obszarów }\end{array}$ & $\begin{array}{l}\text { Jednostka } \\
\text { dokonała opisu } \\
\text { polityk odnośnie } \\
\text { do wszystkich } \\
5 \text { obszarów }\end{array}$ & $\begin{array}{l}\text { Jednostka } \\
\text { dokonała opisu } \\
\text { polityk odnośnie } \\
\text { do wszystkich } \\
5 \text { obszarów }\end{array}$ & $\begin{array}{l}\text { Jednostka } \\
\text { dokonała opisu } \\
\text { polityk odnośnie } \\
\text { do wszystkich } \\
5 \text { obszarów }\end{array}$ \\
\hline $\begin{array}{l}\text { Opis procedur } \\
\text { należytej staranności } \\
\text { w odniesieniu do } \\
\text { zagadnień: } \\
\text { - społecznych, } \\
\text { - pracowniczych, } \\
\text { - środowiska } \\
\text { naturalnego, } \\
\text { - poszanowania } \\
\text { praw człowieka } \\
\text { - przeciwdziałania } \\
\text { korupcji }\end{array}$ & $\begin{array}{l}\text { Spółka } \\
\text { przedstawiła } \\
\text { w formie } \\
\text { tabelarycznej } \\
\text { badania } \\
\text { realizowane } \\
\text { w } 2018 \text { roku } \\
\text { w ramach } \\
\text { procedur } \\
\text { należytej } \\
\text { staranności }\end{array}$ & $\begin{array}{l}\text { Brak jest } \\
\text { bezpośredniego } \\
\text { określenia } \\
\text { procedur należytej } \\
\text { staranności } \\
\text { w odniesieniu } \\
\text { do } 5 \text { obszarów }\end{array}$ & $\begin{array}{l}\text { Brak jest } \\
\text { bezpośredniego } \\
\text { określenia } \\
\text { procedur należytej } \\
\text { staranności } \\
\text { w odniesieniu } \\
\text { do } 5 \text { obszarów }\end{array}$ & $\begin{array}{l}\text { Jednostka } \\
\text { dokonała } \\
\text { opisu procedur } \\
\text { w ramach } \\
\text { wszystkich } \\
5 \text { obszarów }\end{array}$ \\
\hline $\begin{array}{l}\text { Opis istotnych } \\
\text { rodzajów ryzyka } \\
\text { związanych } \\
\text { z działalnością } \\
\text { jednostki mogących } \\
\text { wywierać } \\
\text { niekorzystny wpływ }\end{array}$ & $\begin{array}{l}\text { Opis ryzyka } \\
\text { odnośnie do } \\
8 \text { obszarów } \\
\text { funkcjonowania } \\
\text { firmy }\end{array}$ & $\begin{array}{l}\text { Czytelny } \\
\text { tabelaryczny opis } \\
\text { ryzyka w stosunku } \\
\text { do wszystkich } \\
\text { obszarów } \\
\text { wymaganych } \\
\text { w ustawie }\end{array}$ & $\begin{array}{l}\text { Czytelny } \\
\text { tabelaryczny opis } \\
\text { ryzyka w stosunku } \\
\text { do wszystkich } \\
\text { obszarów } \\
\text { wymaganych } \\
\text { w ustawie }\end{array}$ & $\begin{array}{l}\text { Opis ryzyka } \\
\text { w odniesieniu do } \\
\text { wszystkich } \\
5 \text { obszarów }\end{array}$ \\
\hline
\end{tabular}


Tabela 2, cd.

\begin{tabular}{|c|c|c|c|c|}
\hline 1 & 2 & 3 & 4 & 5 \\
\hline $\begin{array}{l}\text { na zagadnienia, } \\
\text { o których mowa } \\
\text { w pkt } 3 \text {, w tym } \\
\text { ryzyka związanego } \\
\text { z produktami } \\
\text { jednostki lub } \\
\text { jej relacjami } \\
\text { z otoczeniem } \\
\text { zewnętrznym, w tym } \\
\text { z kontrahentami, } \\
\text { a także opis } \\
\text { zarządzania tymi } \\
\text { rodzajami ryzyka }\end{array}$ & & & & \\
\hline
\end{tabular}

Źródło: opracowanie własne na podstawie: Sprawozdania Zarządu z działalności Enea SA oraz grupy kapitałowej Enea w 2018 r., Jednostkowego Raportu Rocznego TAURON Polska Energia SA za 2018 r., Sprawozdania na temat informacji niefinansowych PGE Polskiej Grupy Energetycznej SA oraz Grupy Kapitałowej PGE za 2018 rok, a także raportu CSR Spółki Energa.

Jak wynika z tab. 2, analizowane spółki starannie opisały swój model biznesowy i działania podejmowane w celu jego doskonalenia. Opis modelu zawierał dodatkowo graficzne prezentacje dotyczące:

1. Strategii rozwoju grupy kapitałowej (Enea, Energa).

2. Kierunków zrównoważonego rozwoju grupy (Tauron).

3. Mapy interesariuszy (Tauron).

4. Bezpośredniego i pośredniego zaangażowania kapitałowego (PGE).

5. Całego łańcucha wartości (PGE).

Wszystkie analizowane przedsiębiorstwa przedstawiły kluczowe niefinansowe wskaźniki/mierniki efektywności, ale z tekstu raportu nie zawsze można było wnioskować, które z nich są tak naprawdę kluczowe przy podejmowaniu strategicznych i operacyjnych decyzji dotyczących działania jednostki (Energa). Celem zapisu ustawy o rachunkowości było natomiast zobligowanie jednostek do ujawniania kilku kluczowych wskaźników niefinansowych, które razem ze wskaźnikami finansowymi mogą być strategiczne przy podejmowaniu decyzji dotyczących funkcjonowania przedsiębiorstwa [Raportowanie 2017]. Dobrą praktyką wszystkich analizowanych spółek energetycznych jest z kolei przedstawienie wskaźnika średniego czasu trwania wyłączenia zasilania (SAIDI - Enea, Tauron, Energa, PGE), który jest dla tych przedsiębiorstw strategiczny, mimo że nie dotyczy on pięciu obszarów, o których mowa w art. 49b ustawy o rachunkowości. Dzięki temu wskaźnikowi interesariusze otrzymują użyteczne informacje dla podejmowania decyzji strategicznych i operacyjnych. Na podkreślenie zasługuje także to, iż w odniesieniu do działalności środowiskowej spółki Enea, Energa, PGE zaprezentowały wskaźniki środowiskowe zgodnie z międzynarodowymi wytycznymi Global Reporting Initiative (GRI). 
Jednostki opisały w sposób przejrzysty i syntetyczny stosowane polityki w odniesieniu do zagadnień: społecznych, pracowniczych, środowiska naturalnego, poszanowania praw człowieka, przeciwdziałania korupcji. Najszerzej prezentowane były aspekty środowiskowe, które pokazują realizowane już działania, a także zobowiązanie do podejmowania działań, które spowodują zmniejszenie niekorzystnego oddziaływania na środowisko przyrodnicze. Niemniej jednak w żadnym raporcie nie zawarto informacji o dotychczasowym niekorzystnym działaniu na środowisko i konieczności prowadzenia polityki w tym zakresie. Wszelkie niekorzystne oddziaływania mogące wystąpić w przyszłości spółki opisały w ramach punktu piątego wymogów ustawy i określiły je „ryzykiem niekorzystnego oddziaływania”. Większość firm użyła także określenia „polityka”, a nie tylko opisu podejmowanych działań i stosowanych zasad, co także świadczy o dostosowaniu się do wymogów ustawy. W przypadku spółki Energa brak jest określenia „,polityka” tylko w odniesieniu do obszaru przeciwdziałania korupcji, wspomniane jest jednak o posiadaniu dokumentu ,polityka przeciwdziałania nadużyciom i konfliktowi interesów”.

Przez procedury należytej staranności - w kontekście raportowania niefinansowego - powinno się rozumieć szczegółowe procedury stosowane przez jednostkę lub grupę kapitałową, których celem byłoby zapewnianie skuteczności polityki stosowanej w danym obszarze [Raportowanie 2017]. Jak wynika z dokonanej analizy, nie wszystkie spółki zaprezentowały opis procedur należytej staranności. Tylko dwie (Tauron, Enea) opisały swoje podejście do tematu należytej staranności w odniesieniu do wszystkich obszarów wymienionych w ustawie. W pozostałych spółkach procedury zostały opisane, lecz nie nazwano ich wprost ,procedurami należytej staranności”

Spółki Enea, Tauron, Energa, PGE zaprezentowały czytelną tabelę prezentującą zidentyfikowane rodzaje ryzyka i powiązanie ich z zagadnieniami społecznymi, pracowniczymi, środowiskowymi, przeciwdziałaniem korupcji, a także zagadnieniami związanymi z prawami człowieka. Oprócz opisu ryzyka w odniesieniu do pięciu obszarów spółka Enea prezentuje także ich ocenę zgodną ze skalą oceny ryzyka korporacyjnego. Spółka Tauron umieściła z kolei tabelę prezentującą ryzyko mogące wywierać niekorzystny wpływ na polityki stosowane przez Grupę Kapitałową oraz opis reakcji na ryzyko w stosunku do innych obszarów, niż wymienia ustawa, a mianowicie w stosunku do ryzyka: społecznego, zarządzania kapitałem ludzkim, BHP, komunikacji wewnętrznej, środowiskowego, procesu zakupowego, prawnego, compliance.

\section{Zakończenie}

Przeprowadzona ocena wybranych obszarów raportowanych informacji niefinansowych w kontekście podstawowych cech jakościowych sprawozdania finansowego pozwala na sformułowanie następujących wniosków:

1. Zgodnie z definicją Garsteckiego [2014] prezentowane informacje niefinansowe są przydatne, ponieważ są rzetelne i odpowiednio uszczegółowione w sposób 
pozwalający odbiorcy na podjęcie właściwych decyzji. W odniesieniu zaś do definicji K.R. Poppera [Garstecki 2014], według którego sprawozdanie, które nie jest porównywalne, nie jest przydatne dla interesariuszy, można wnioskować, że informacje niefinansowe nie są przydatne. Autorka artykułu uważa, że sposób badania przydatności powinien być oceniany indywidualnie z perspektywy oczekiwań konkretnej grupy interesariuszy sprawozdań prezentujących informacje niefinansowe.

2. Do cech fundamentalnych zintegrowanego raportowania, oprócz istotności i rzetelności, należałoby zaliczyć również cechę terminowości. Informacja powinna trafić do użytkownika, zanim straci ona znaczenie przy podejmowaniu przez niego decyzji [Szczepankiewicz 2013]. Biorąc pod uwagę tę cechę sprawozdań, można stwierdzić, że jednostki będące przedmiotem analizy wywiązują się z tego zadania, publikują bowiem na swoich stronach internetowych raporty zgodnie $\mathrm{z}$ terminami ustalonymi w ustawie (6 miesięcy od dnia bilansowego).

3. Obszerna prezentacja przez spółki zagadnień związanych ze środowiskiem, społecznością, działaniami inwestycyjnymi powoduje wzrost wiarygodności publikowanych informacji i jednocześnie powoduje wzrost zaufania interesariuszy do generowanych przez spółki informacji nie tylko niefinansowych, ale w konsekwencji także finansowych.

4. Porównywalność to $\mathrm{z}$ kolei cecha, która w przypadku tych spółek nie jest całkowicie spełniona. Zgodnie bowiem z Wytycznymi GRI raporty i zawarte w nich informacje są porównywalne, jeżeli (por: [Kamela-Sowińska 2015]):

- można porównać je w ujęciu okres do okresu (analiza dynamiki i tendencji zmian),

- uzyskane wyniki, np.: wskaźników, można porównać z odpowiednimi wielkościami będącymi punktami odniesienia,

- wszelkie istotne odchylenia są możliwe do zidentyfikowania i wyjaśnienia,

- wykorzystuje się w raporcie powszechnie przyjęte zasady gromadzenia, pomiaru i prezentacji informacji.

Za najistotniejszą cechę porównywalności według autorki można natomiast uznać możliwość porównania sprawozdań i zawartych w nich informacji w stosunku do innych jednostek. Badane sprawozdania nie są porównywalne, co spowodowane zostało możliwością wyboru przez jednostkę formy i brakiem jednoznacznego określenia zakresu prezentowania informacji niefinansowych. Takie same wyniki przyniosły badania przeprowadzone przez Sikacz i Wołczek [2017], w których analizie poddano spółki z Respect Index.

5. Prezentowane $\mathrm{w}$ raportach informacje niefinansowe można uznać za użyteczne. Raporty mają dużą wartość informacyjną, co powoduje, że są korzystne dla interesariuszy w realizacji celów decyzyjnych, przekazane na czas, niezawodne, istotne. Niniejszy artykuł potwierdził tym samym wnioski z badań przeprowadzone przez Dyczkowskiego [2015, s. 84-96] i Gordona i in. [2010, s. 210] oraz Van der Veekena i Woutersa [2002, s. 347]. 
6. Biorąc pod uwagę zasady określające przejrzystość prezentowane przez standardy GRI, na które składają się: równowaga, porównywalność, dokładność, terminowość, jasność, można stwierdzić, że przeprowadzona ocena przejrzystości prezentowanych informacji niefinansowych wskazuje braki w odniesieniu m.in. do tematyki związanej z niekorzystnym oddziaływaniem na środowisko, koniecznością prowadzenia polityki w tym zakresie, a także opisem polityki należytej staranności. Podobne wyniki uzyskano w badaniu przeprowadzonym przez KPMG w 2013 roku, podczas którego zbadano 4100 raportów firm z 41 krajów. Tylko 23\% firm G 250 osiągnęło odpowiedni poziom przejrzystości [Szadziewska 2014].

Niniejszy artykuł potwierdził zatem część wyników przeprowadzonych dotychczas badań. W kolejnym etapie należałoby sprawdzić, jakie czynniki wpływają na polepszenie przejrzystości, a tym samym pozostałych cech jakościowych prezentowanych w sprawozdaniu z działalności i porównać wyniki do międzynarodowych badań przeprowadzonych m.in. przez autorów, takich jak Fernandez-Feijo i in. [2014] oraz Tagesson i in. [2009].

\section{Literatura}

Bek-Gaik B., Krasodomska J. (2018), Informacje niefinansowe jako obszar wspótczesnej sprawozdawczości przedsiębiorstw - definicja, źródła i proponowane kierunki badań, Zeszyty Naukowe Uniwersytetu Ekonomicznego w Krakowie, 2(974).

Dyczkowski T. (2015), Użyteczność informacji niefinansowych w ocenie dokonań organizacji pożytku publicznego, Prace Naukowe Uniwersytetu Ekonomicznego we Wrocławiu, 389.

Fernandez-Feijoo B., Romero S., Ruiz S. (2014), Effect of stakeholders' pressure on transparency of sustainability reports within the GRI framework, Journal of Business Ethics, 122(1), 53-63.

Garstecki D. (2014), Porównywalność a przydatność sprawozdań finansowych. Analiza w ujęciu metodologi K.K. Poppera, Studia Oeconomica Posnaniensia, vol. 2, nr 4, s. 7-22.

Gazdar K. (2007), Reporting Nonfinancials, John Wiley \& Sons, London.

Gernon H., Meek G.K. (2001), Accounting. An International Perspective, MCGraw-Hill, Singapore, 71-72.

Gordon T.P., Khumawala S.B., Kraut M., Neely D.G. (2010), Five dimensions of effectiveness for non-profit annual reports, Nonprofit Management \& Leadership, vol. 21, issue 2.

Jaruga A., Frendzel M., Ignatowski R., Kabalski P. (2009), Międzynarodowe Standardy Sprawozdawczości Finansowej (MSSF/MSR) 2009. Najnowsze zmiany, SKwP, Warszawa.

Kamela-Sowińska A. (2015), Skutki ekonomiczne realizacji umowy społecznej jako podstawy raportów CSR, Studia Oeconomica Posnaniensia, 3(1), Wydawnictwo Uniwersytetu Ekonomicznego, Poznań.

Krasodomska J. (2014), Informacje niefinansowe w sprawozdawczości spótek, Zeszyty Naukowe Uniwersytetu Ekonomicznego w Krakowie, Seria specjalna: Monografie, nr 232, Wydawnictwo Uniwersytetu Ekonomicznego w Krakowie, Kraków.

Luft J. (2009), Nonfinancial information and accounting: A reconsideration of benefits and challeges, Acounting Horizons, 23(3), 307-325.

Maines L.E. Bartov P.M., Fairfield Hirst D.E., Iannaconi T.E., Mallett R., Schrand C.M., Skinner D.J., Vincent L. (2002), Recommendations on disclosure of nonfinancial performance measures, Accounting Horizons 16, 4, 353-362. 
Międzynarodowe Standardy Sprawozdawczości Finansowej (2011), SKwP, Warszawa.

Rówińska M. (2013), Cechy jakościowe sprawozdania finansowego jednostek gospodarczych, Finanse, Rynki Finansowe, Ubezpieczenia, (58), 377.

Samelak J. (2013), Zintegrowane sprawozdanie przedsiębiorstwa społecznie odpowiedzialnego, Wydawnictwo Uniwersytetu Ekonomicznego w Poznaniu, Poznań.

Sikacz H., Wołczek P. (2017), Analiza raportów informacji niefinansowych spótek z RESPECT Index, Marketing i Rynek, (11 (CD), 540-552.

Sobczyk M. (2017), Zakres pojęciowy terminu ,informacja niefinansowa” jako źródto zróżnicowania ujawnień niefinansowych przedsiębiorstw, Finanse. Rynki Finansowe. Ubezpieczenia, 4(88), cz. 1.

Stolowy H., Paugam L. (2018), The expansion of non-financial reporting: an exploratory study, Accounting and Business Research, 48(5), 525-548.

Szadziewska A. (2014), Prezentowanie informacji na temat społecznej odpowiedzialności w sprawozdawczości zewnętrznej przedsiębiorstw, Prace Naukowe Uniwersytetu Ekonomicznego we Wrocławiu (329), 264.

Szczepankiewicz E. (2013), Definiowanie zakresu, zasięgu i jakości zintegrowanego sprawozdania, Prace Naukowe Uniwersytetu Ekonomicznego we Wrocławiu (314), 174-189.

Tagesson T., Blank V., Broberg P., Collin S. O. (2009), What explains the extent and content of social and environmental disclosures in corporate websites, A Study of Social and Enviro Responsibility and Environmental Management, 16, 352-364.

Upton W.S. (2001), Business and Financial Reporting: Challenges from the New Economy, Norwalk, CT, FASB.

Ustawa z dnia 29 września 1994 roku o rachunkowości (tekst jedn. Dz.U. 2018, poz. 39 z późn. zm.).

Van der Veeken H.J.M., Wouters M.J.F. (2002), Using accounting information systems by operations managers in a project company, Management Accounting Research, nr 13.

Walińska E., Bek-Gaik B., Gad J. (2018). Informacje finansowe i niefinansowe w raporcie zintegrowanym - praktyka spółek notowanych na Giełdzie Papierów Wartościowych w Warszawie, Zeszyty Teoretyczne Rachunkowości, 100(156), 167-189.

Zyznarska-Dworczak B. (2016), Rozwój sprawozdawczości niefinansowej a możliwości jej zewnętrznej weryfikacji, Studia Ekonomiczne. Zeszyty Naukowe. Zeszyty Naukowe Uniwersytetu Ekonomicznego w Katowicach, Katowice, nr 286. 